\title{
TWO NEW INDIAN EMBIOPTERA AND THE LECTOTYPE OF OLIGOTOMA BORNEËNSIS HAGEN ${ }^{1}$
}

\author{
By Edward S. Ross \\ California Academy of Sciences, San Francisco
}

EMBIIDA

Metembia flava Ross, new species

(Figures 1 to 5 )

Holotype male (on slide): Color - pale yellow throughout, head and thorax somewhat darker, wings light brown, abdominal terminalia with tenth tergite and basal segment of left cercus tan. Dimensions - length $7.5 \mathrm{~mm}$.; fore-wing length $3.57 \mathrm{~mm}$., breadth $1.0 \mathrm{~mm}$.

Head (fig. 1) with form as illustrated, very weakly pigmented throughout except the mandibles which have golden-brown apices.

Wings with hyaline stripes very broad, margins ragged. $\mathrm{R}_{1}$ nearly attaining wing apex, slightly curved toward $R_{2+3}$ and $R_{4}$.

Hind basitarsi (fig. 5) with two conspicuous sole-bladders.

Terminalia (figs. 2 to 4 ) with left tergal process (10 LP) small, short; form as illustrated (fig. 3). Right hemitergite $(10 \mathrm{R})$ with a cone-like caudal projection $\left(10 \mathrm{RP}_{1}\right)$ which terminates as a minute sclerotic point; secondary process $\left(10 \mathrm{RP}_{2}\right.$ ) represented as a long, longitudinally folded, submembranous area closely paralleling inner side of $10 \mathrm{~L}$ and terminating as a small rounded lobe. Hypandrium $(\mathrm{H})$ scarcely pigmented, outline inconspicuous, quadrate; caudally produced medially as a short, broadly rounded lobe (HP). Composite left cercus-basipodite and left paraproct (LCB + LPPT) with caudal margin somewhat sclerotized, posterior angle with a roughened, pigmented lobe. Composite right paraproct

\footnotetext{
${ }^{1}$ Published with the aid of a grant from the Museum of Comparative Zoölogy at Harvard College. The material upon which this paper is based is from the Museum. The writer is grateful to Professor Nathan Banks for permission to study these specimens.
} 
( RCB + RPPT) inconspicuous, apparently partially fused to $\mathrm{H}$ at base and curving around inner base of right cercus. Basal segment of left cercus $\left(\mathrm{LC}_{1}\right)$ sclerotized, especially along inner margin, cylindrical with a broadly expanded basal foramen and a slightly swollen apex; a weakly inflated, inner basal lobe bears seven very stout, curved "teeth"; the terminal lobe bears

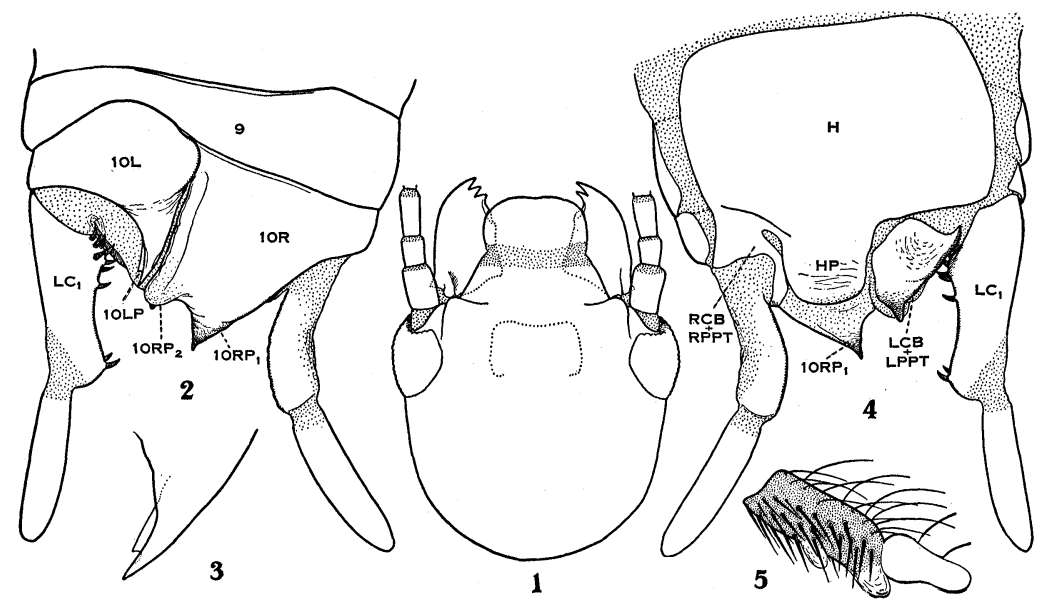

Figures 1 to 5, Metembia flava n. sp., holotype male: fig. 1, head; fig. 2, terminalia (dorsal) ; fig. 3, detail of $10 \mathrm{LP}$; fig. 4, terminalia (ventral) ; fig. 5, left hind basitarsus.

Explanation of symbols: $9=9$ th tergite $; 10 \mathrm{~L}$ and $10 \mathrm{R}=$ Left and right hemitergites of tenth segment; $10 \mathrm{LP}=$ left tergal process; $10 \mathrm{RP}_{1}=$ major right tergal process; $10 \mathrm{RP}_{2}=$ secondary right tergal process; $\mathrm{H}=$ hypandrium (9th sternite); $\mathrm{HP}=$ hypandrium process; $\mathrm{LCB}$ and $\mathrm{RCB}=$ left and right cercus-basipodites; RPPT and LPPT $=$ left and right paraprocts $; \mathrm{LC}_{1}=$ basal segment of left cercus. All drawings are based on Camera Lucida outlines; setæ are omitted; stippling represents membrane; the outline of submentum is dotted.

only two such "teeth." Basal segment of right cercus almost entirely membranous; terminal segments of both cerci normal in shape, but submembranous.

Female: Unknown.

Holotype: Male, on slide, from Nedungadu, Tanjore, South India, May 2 (P. S. Nathan). Deposited in Museum of Comparative Zoölogy.

Paratype: Male, on slide, with type data but collected February 14 . Deposited in the writer's collection.

Flava cannot be confused with the other species of Metembia 
Davis, i.e., ferox Davis (1939a, p. 474) and immsi Davis (1939a, p. 475). It may be separated from both by its small size, pale color, short left tergal process (10 LP), and the slight lobes of $\mathrm{LC}_{1}$ with the few stout "teeth" (echinulations). Both ferox and immsi have very pronounced basal and apical inner lobes on $\mathrm{LC}_{1}$ bearing numerous echinulations.

The paratype differs from the holotype only in its more swollen caudal lobe of the composite left paraproct and its possession of three "teeth" on the apical lobe of $\mathrm{LC}_{1}$ instead of two.

\section{Family Oligotomid}

\section{Oligotoma borneensis Hagen}

(Figures 6 to 8 )

Oligotoma borneensis Hagen, 1885, Can. Ent., 17:146 (as "O. saundersii Westw.") (Lectotype male: Telang Borneo, M.C.Z.) ; ${ }^{1}$ Krauss, 1911, Zoölogica, 23:39 (= "O. saundersii Westw."); Davis, 1940, Proc. Linn. Soc. N.S.W., 65:371, figs. 23-37 (establishes identity). ${ }^{2}$

Aposthonia vosseleri Krauss, Ibid., p. 48, pl. II, fig. 14 (Holotype male: Pedang, Sumatra, Stuttgart Mus.) $;{ }^{3}$ Friederichs, 1934, Arch. Naturg., N.F., 3:409, 410 (v. vosseleri), 427 ( o ) ; ${ }^{4}$ Davis, Ibid., p. 373 (= borneënsis Hagen).

Oligotoma vosseleri (Krauss). Enderlein, 1912, Coll. zool. Selys. Longch., 3:101, fig. 65; Silvestri, 1912, Tijd. voor Ent., 55:334, fig. 6 (Java).

Aposthonia vosseleri intermedia Friederichs, Ibid., p. 410 (as a form) (Kuala-Lumpur); ${ }^{5}$ Davis, Ibid., p. 374 (= borneënsis Hagen).

Aposthonia vosseleri obscura Friederichs, Ibid., p. 412; Davis, Ibid., p. 375 (= borneënsis Hagen).

Oligotoma jacobsoni Silvestri, 1912, Tijd. voor Ent., 55:334 (Holotype male: Semarang, Java; Silvestri Coll.); ${ }^{6}$ Davis, Ibid., p. 373 (= borneënsis Hagen).

Aposthonia vosseleri jacobsoni (Silvestri). Friederichs, Ibid., p. $411 .^{7}$

Oligotoma moerens Roepke, 1919, Treubia, 1:5, figs. (Merbabu, Java); ${ }^{8}$ Davis, Ibid., p. 374 (= borneënsis Hagen).

Oligotoma nana Roepke, Ibid., p. 20, figs. (Merbabu, Java); Davis, Ibid., p. 374 (= borneënsis Hagen). 
Aposthonia vosseleri nana (Roepke). Friederichs, Ibid., p. $412 .^{9}$

Oligotoma masi Navás, 1923, Mem. Pont. Accad. Romana Nuovi Lincei, (2) 6:39 (Holotype male: Vigan, Luzon, P. I., Paris Mus.); ${ }^{10}$ Navás, 1932, Ibid., 16:923 (Tonkin record); Davis, Ibid.; p. 374, fig. 32 (= borneënsis, Hagen, vide., reference to masi type).

Davis (1940) has regarded as valid the name borneënsis which was first used by Hagen $(1885$, p. 146) but neglected by most later students of the order. Hagen had before him eight specimens of Oligotoma from Borneo which, from the wording of his discussion, he had at one time intended to name as a new species "O. borneensis," but at the time of writing decided it more prudent to assign to "saundersii Westwood." His description intended to apply to the name "saundersii" was apparently based solely on these Borneo specimens. It is now clear that this material did indeed represent a new species and not "saundersii." Since Hagen's borneënsis was a new name associated with a description it appears that it must be recognized as valid.

Hagen's eight Borneo specimens are today well preserved in the Museum of Comparative Zoölogy, Harvard University. Four of these, in alcohol, from "Telang Borneo, 12.81," labelled in Hagen's hand, "Olig. Borneense Hag.," may be regarded as the cotype series. Davis redescribed and figured two uncleared specimens from this series but failed to designate a lectotype. Through the kindness of Dr. Nathan Banks the writer has been permitted to clear and mount two of the cotypes on slides and to designate one as the lectotype. The following brief description and the accompanying figures are based on this specimen.

Lectotype male (on slide): Color - head pale golden-brown; basal antennal segment chocolate-brown, flagellar segments light brown at base becoming tan distad; mandibles dark mahoganybrown throughout; submentum dark golden-brown. Pterothorax, legs and wings tan; prothorax and abdomen (except terminalia) paler tan; terminalia varying shades of brown. Dimensions - length $10.5 \mathrm{~mm}$., fore-wing length $6 \mathrm{~mm}$., breadth $1.6 \mathrm{~mm}$.

Head and terminalia as figured (figs. 6 to 8 ).

Salient features: Mandibles deeply excised just behind acute medial tooth; basal half massive, with a very pronounced, hirsute, dorsal elevation along outer margin which abruptly 
arises just within basal half and continues to the articulation point. Terminalia with left tergal process (10 LP) elongate, slender, narrowly rounded distad; right process $\left(10 \mathrm{RP}_{1}\right)$ with a small but distinct, subterminal outer point; hypandrium process (HP) simple, rounded; left paraproct (LPPT) narrow,

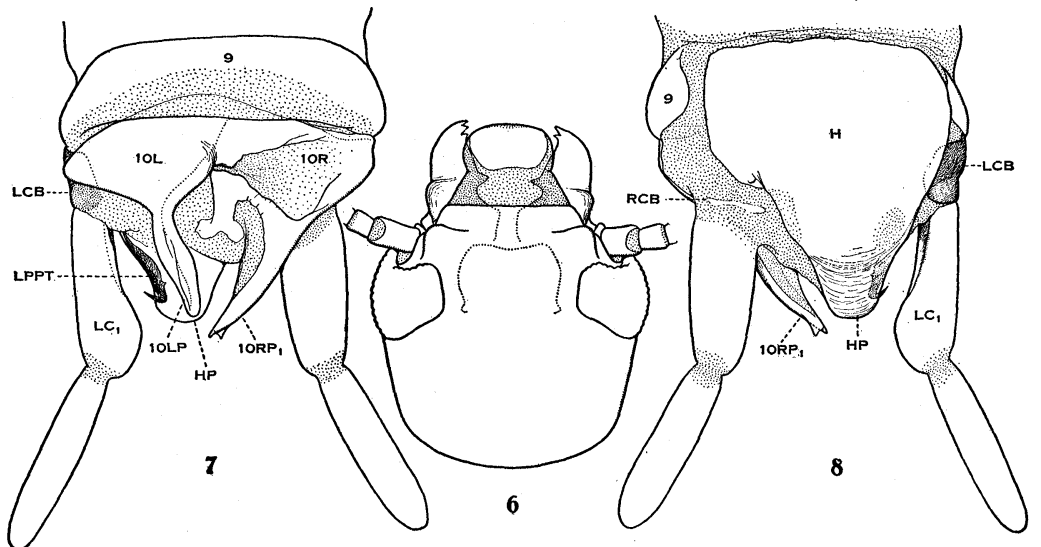

Figures 6 to 8, Oligotoma bornë̈nsis Hagen, Lectotype male: fig. 6, head; fig. 7, terminalia (dorsal); fig. 8, terminalia (ventral). Explanation of symbols under figs. 1 to 5 .

sclerotic, hooked outward and upward terminally and acutely pointed; left cercus-basipodite (LCB) represented only by a nearly black plate at outer base of left cercus; left cercus with basal segment $\left(\mathrm{LC}_{1}\right)$ dilated distad.

Lectotype: male, on slide, from "Telang, Borneo, 12.81," Hagen Collection, deposited in the Museum of Comparative Zoölogy.

Cotypes: three males, one on slide, two in alcohol, same data and disposition.

Additional specimens examined: 1 male, Nan, Siam, I-28 (Alice Mackie) (U.S.N.M.); 1 male, Pattam, Tonkin, IV-1229, at light (R. E. Wheeler) (M.C.Z.) ; 3 males, Dwa Bi, and 2 males Ta Han, Hainan, VI-25, VII-5, 20, 25-35 (L. Gressitt) (M.C.Z.).

Recorded distribution ${ }^{2}$ (based on males): BORNEOTelang, ${ }^{1}$ Lambang Hiang, ${ }^{1}$ Duson Timor; ${ }^{1}$ JAva - Buitenzorg, ${ }^{2,4,5}$ Malang, ${ }^{5,7}$ Gehassen, ${ }^{9}$ Semarang, ${ }^{6}$ Merbabu; ${ }^{8}$ Suma-

${ }^{2}$ Exponential numbers refer to bibliographic citations on page 104. 
TRA - Fort de Kock, ${ }^{4,7}$ Padang ${ }^{3}$ ( ? Simalur, ${ }^{4}$ ) Lasikin ${ }^{4}$ Laut Tawar, ${ }^{4}$ Sibigo $;{ }^{4}$ Ceylon ${ }^{3}$ (misidentification?); Kuala LumPUR; ${ }^{5}$ TonkIn - Pattam; ${ }^{2}$ HaInan - Dwa Bi, ${ }^{2}$ Ta Han $;{ }^{2}$ China - Canton. ${ }^{5}$

The synonymy treated above follows Davis (1940); the writer feels, however, that some portions require confirmation by examination of types. Oligotoma morens Roepke, for example, may prove to be related to ceylonica Enderlein (cf. shape of head, mandibles, and $10 \mathrm{LP}$ ) as a representative or relative of that species has been seen by the writer from Sumatra (Langkat, M.C.Z. Coll.). Particular attention should be given to mandibular structure for recognition of borneënsis as the terminalia characters of this series of species may be very similar.

Borneënsis is a well-defined, wide-spread species in South East Asia and the East Indies (perhaps extended to this range by human transport). It is a member of the large group of species which have the left cercus-basipodite incomplete or obsolete, as opposed to the saundersii group (vide infra) in which this structure is a complete ring with a prominent inner lobe. Within this group it may be placed with those species which have the left paraproct (LPPT) sclerotized and caudally terminated as a small, sharp point which is turned outward, i.e., varians Navás (1923) from Kwantung, China, scottiana Enderlein (1910) from the Seychelles, and thoracica Davis (1940) from Burma. There may be additional species which have this combination of characters, if so it is not evident from available descriptions. Albertisi Navás (1930) from New Guinea is probably also a relative but the left paraproct is not produced as a sharp point. A brief key to these species follows:

1. Left tergal process (10 LP) tapered, narrowly rounded, or slightly hooked outward distally

Left tergal process slightly expanded and obliquely truncate distad. Burma

thoracica Davis

2. Left tergal process narrow, elongate, narrowly rounded at tip

Left tergal process rather broad, obtusely angulate on inner margin, tip abruptly curved outward at apex (mandibles without dorsal elevations). China.

varians Navás

3. Process of hypandrium (HP) with a subobtuse projection near right apical angle. Seychelles . scottiana Enderlein 
Process of hypandrium evenly rounded, without such a projection. S. E. Asia and East Indies . . borneënsis Hagen

Oligotoma falcis Ross, new species

(Figures 9 to 13)

Holotype male (on slide) Color - Head and submentum blackish-brown, mandibles tan with brown inner margins and apices; remainder of body and appendages medium brown except terminalia which is dark brown. Dimensions - length $8.5 \mathrm{~mm}$.; fore-wing length $5.2 \mathrm{~mm}$., breadth $1.3 \mathrm{~mm}$.

Head (fig. 9) with form illustrated.

Wings as throughout the genus; with three $\mathrm{C}-\mathrm{R}_{1}$ and four

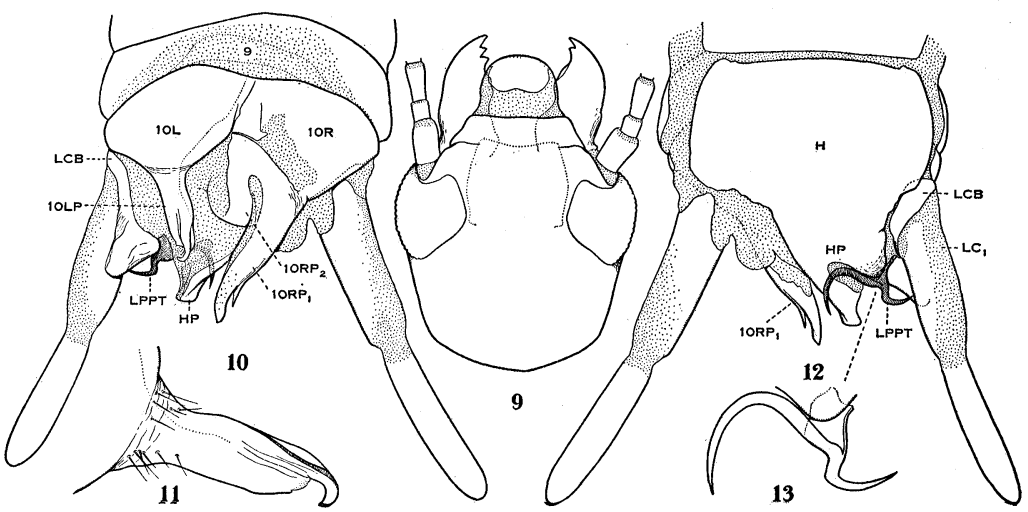

Figures 9 to 13, Oligotoma falcis n. sp., holotype male: fig. 9, head; fig. 10, terminalia (dorsal); fig. 11, detail of $10 \mathrm{LP}$; fig. 12, terminalia (ventral); fig. 13, detail of LPPT (ventral). Explanation of symbols under figs. 1 to 5.

$\mathrm{R}_{1}-\mathrm{R}_{2+3}$ cross-veins in fore-wing; five $\mathrm{C}-\mathrm{R}_{1}$ and six $\mathrm{R}_{1}-\mathrm{R}_{2+3}$ cross-veins in hind-wing. Hyaline stripes narrow, sharply defined.

Terminalia (figs. 10 to 13 ) with left tergal process (10 LP) (fig. 11) rather broad, sides subparallel, abruptly, irregularly convergent distad, especially on left side, terminating as a hook directed to the left. Major right tergal process $\left(10 \mathrm{RP}_{1}\right)$ narrow, sclerotic apically, narrowly truncate; with a prominent, subapical, outer spine which is somewhat appressed. Left paraproct (LPPT) (fig. 13) developed as a complex, sclerotic, horizontal spine; inner portion narrow, sickle-shaped, crossing venter of $\mathrm{HP}$; outer portion shorter, abruptly turned $\left(90^{\circ}\right)$ 
caudad, thence abruptly turned $\left(90^{\circ}\right)$ laterad, tapered distally. Left cercus-basipodite (LCB) membranous laterad but very strongly pigmented and swollen mesad; the inner margin straight, broadly rounded at each end and at least half as long as basal segment of left cercus $\left(\mathrm{LC}_{1}\right)$.

Holotype: Male, on slide, from R. Tunga, at light, 1865 feet elevation, Shimoga, Mysore, South India (P. S. Nathan). Deposited in the Museum of Comparative Zoölogy.

Paratypes: Five topotypic males collected in May and July deposited in the above collection and that of the writer.

One additional male at hand, from Nedungadu, South India, IV-6-(P. S. Nathan), is tentatively assigned to this species. However, if a study of a series reveals that its peculiarities are constant in a definite geographic area, it may be regarded as a subspecies of falcis. This male differs from the above series as follows: Much larger in size, head light brown, submentum golden in color, eyes more strongly inflated sides of head more strongly convergent (the head of the type series varies in form in this direction, but the color is constant); spine of LPPT stouter (this spine though constantly narrow in the series, varies considerably in size and curvature, especially the arm directed laterad).

Falcis is a close relative of saundersii (Westwood) which has been collected at the same locality, but is very distinct from it in many details, e.g., $10 \mathrm{LP}$ is parallel-sided (sides not curved), $10 \mathrm{RP}_{1}$ has the subapical tooth more prominent; LCB is more broadly lobed mesad; the spine of LPPT is much narrower, with its lateral extension greatly developed.

Both species are members of a very natural group of Oligotoma, centered in distribution in the Indian Region (aside from the spread of three species by man, i.e., saundersii, nigra, humbertiana), which is characterized by the prominent, ring-like left cercus-basipodite with its mesal lobe, and a sclerotic, spinelike development of the left paraproct. These species may be separated as follows:

Key to Species of Saundersii Group of Oligotoma (Males)

1. $10 \mathrm{RP}_{1}$ with a prominent subapical spine on outer side 2 $10 \mathrm{RP}_{1}$ without a subapical spine, or when present it is very small and inconspicuous

2. LCB with inner lobe prolonged caudad along inner side of 
left cercus as a narrow process; LPPT without a sickleshaped spine crossing beneath HP

humbertiana (Saussure)

LCB with a simple, broad inner lobe, without a caudal process; LPPT with a sclerotic, sickle-shaped spine crossing beneath HP

falcis Ross

3. LPPT with a broad sickle-shaped spine extending mesad beneath HP; 10 LP broad, spatulate, simple with curved sides ................ saundersii (Westwood)

LPPT not as above; $10 \mathrm{LP}$ narrow, acuminate or sinuous with apex complex

4. 10 LP narrow, gradually tapered distad, simple;

nigra (Hagen)

10 LP broad in basal half, abruptly tapered distad, apex complex greeniana Enderlein

There is a possibility that falcis is identical to Embia bramina Saussure described from Bombay (1896, p. 352) the type of which was incompletely figured by Krauss (1911 pl. I, figs. 6, 6A). Davis (1939, p. 184) regarded this species as a synonym of saundersii but noted that this view should be confirmed by an examination of Saussure's poorly known holotype in the Geneva Museum. For the present it seems more advisable to apply a new name to these specimens than to refer them to such a doubtful and poorly described species as bramina.

\section{Literature Cited}

Davis, C., 1939, Taxonomic notes on the order Embioptera. I. The genotype of Oligotoma Westwood, Proc. Linn. Soc. N.S.W., 64:181-190, 5 figs. 1939a, Taxonomic notes on the order Embioptera, VI. Three new asiatic genera related to Embia Latreille. Ibid., pp. 474-482, 32 figs.

, 1940, Taxonomic notes on the order Embioptera. XVIII. The genus Oligotoma Westwood. Ibid., 65:362-387, 83 figs.

Krauss, H. A., 1911, Monographie der Embien. Zoologica (Stuttgart), 60:1-76, 5 pl., 7 figs.

Saussure, H., 1896, Note sur la Tribus des Embiens. Mitt. Schweiz. Ent. Ges., 9:339-355, pl. 1 .

Navás, L., 1923, Algunos Insectos del Museo de Paris, Rev. Acad. Cienc. Zaragoza, 7 (1922):15-51, 16 figs.

, 1930, Insectos del Museo de París V, Apéndice $2^{\circ}$, Insectos neuvos del Museo de Génova, Broteria, Série Zoológica (Lisbon) 26:20-23, figs. 2-4. 

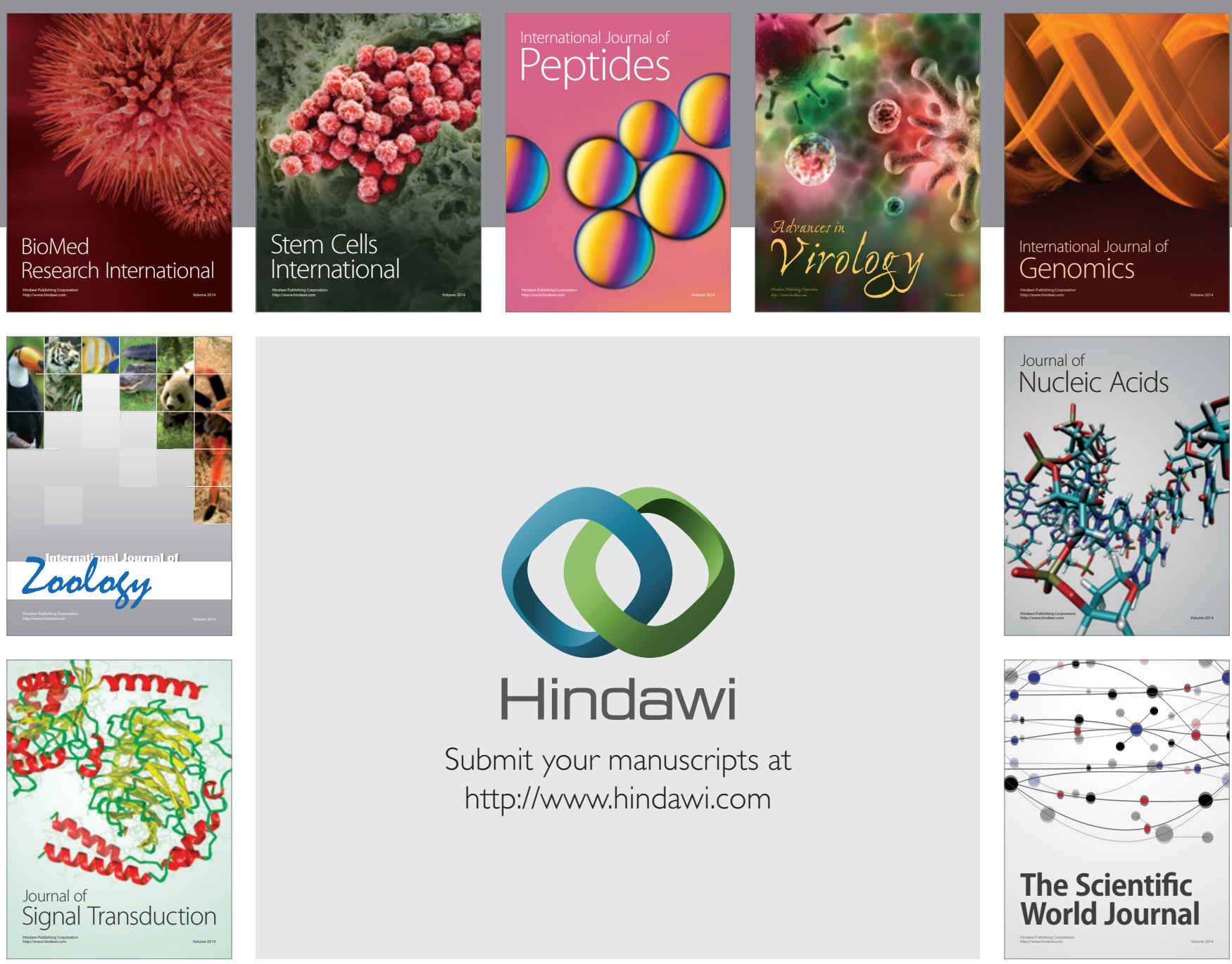

Submit your manuscripts at

http://www.hindawi.com
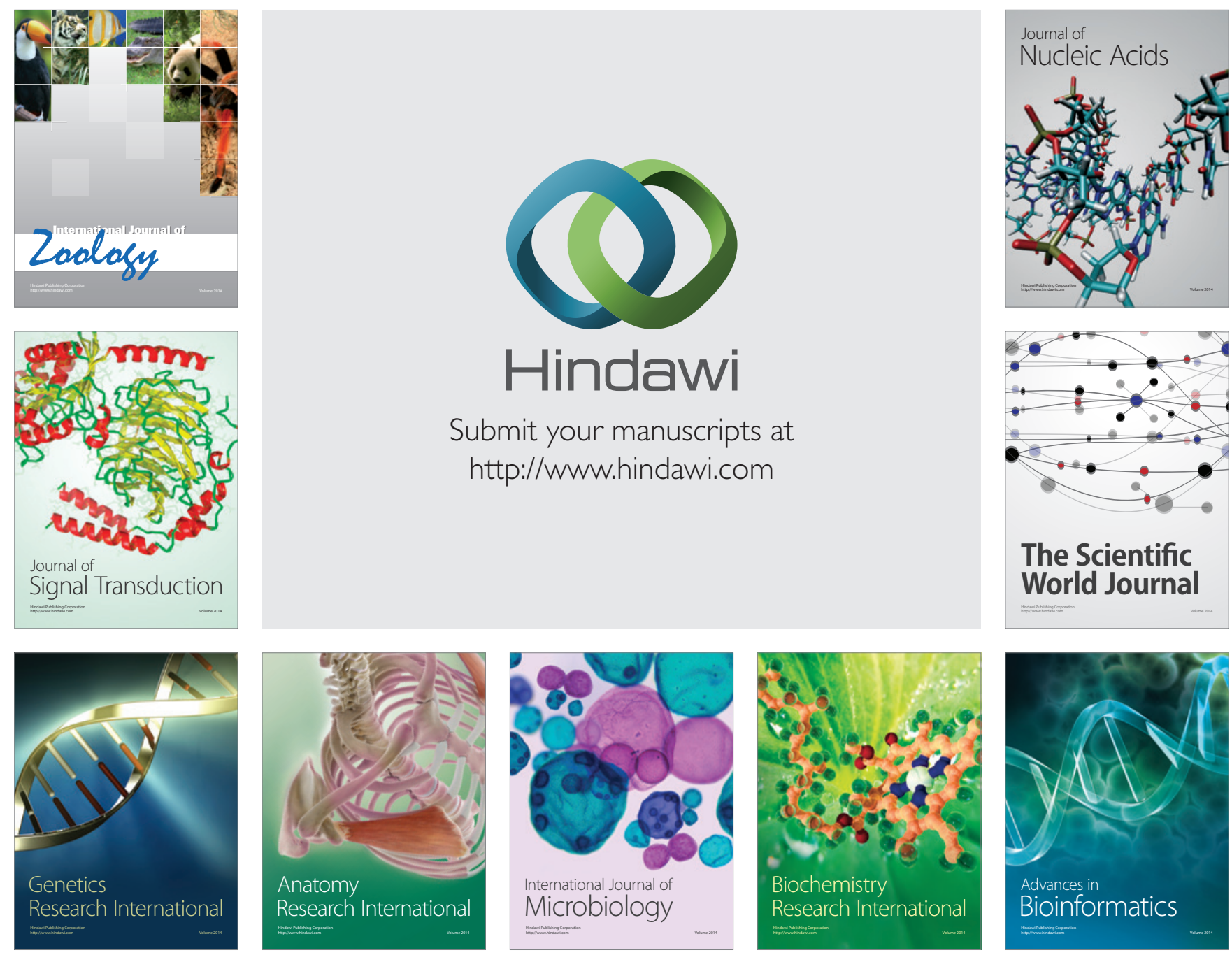

The Scientific World Journal
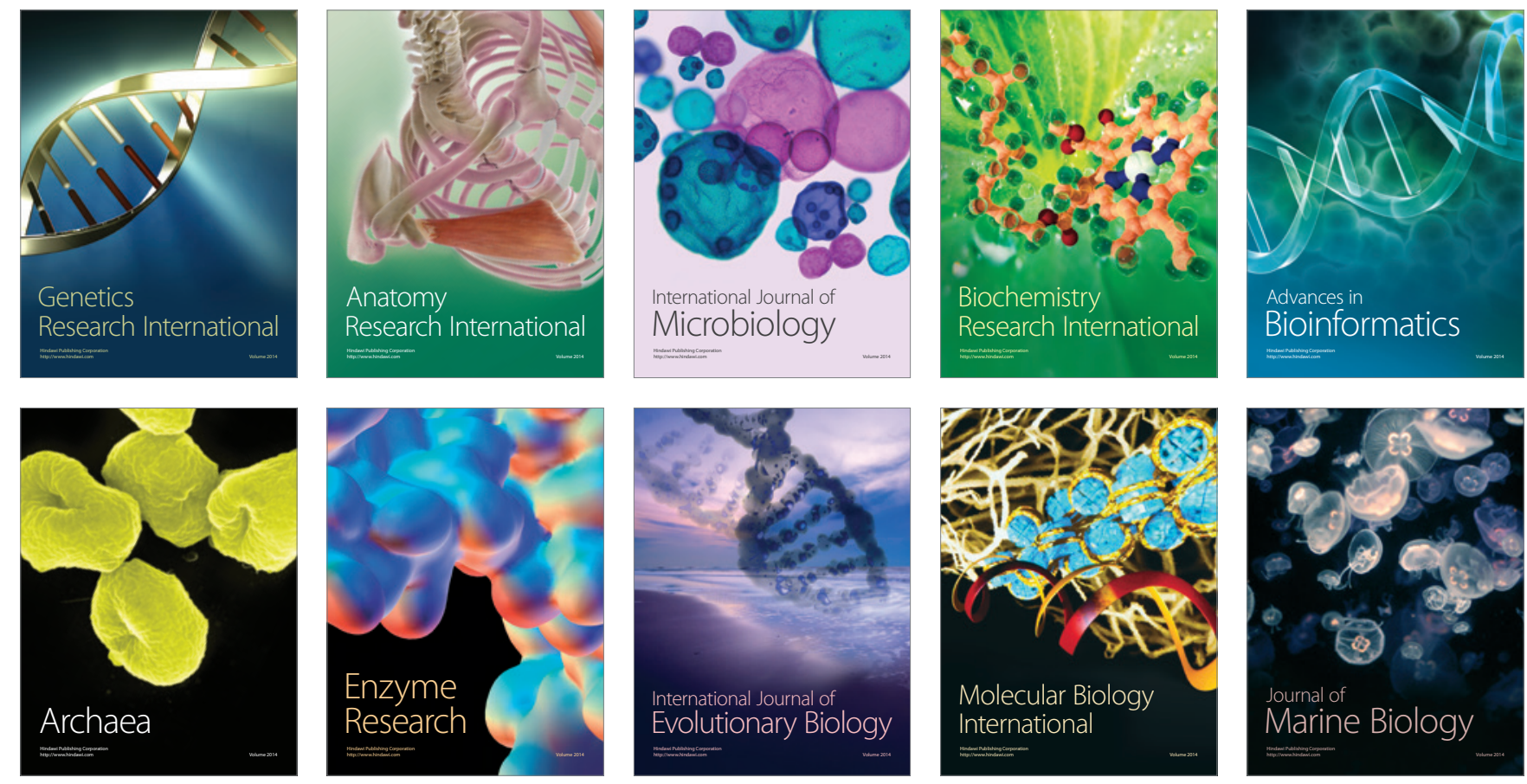